Int. J. Dev. Biol. 51: 571-583 (2007)

doi: $10.1387 / \mathrm{ijdb} .072388 \mathrm{mk}$

\title{
Cellular commitment and differentiation in the organ of Corti
}

\author{
MATTHEW W. KELLEY* \\ Section on Developmental Neuroscience, National Institute on Deafness and other Communication Disorders, \\ National Institutes of Health, Bethesda, Maryland, USA
}

\begin{abstract}
The organ of Corti, the sensory epithelium of the mammalian cochlea, develops from a subset of cells located along the dorsal side (referred to as the floor) of the cochlear duct. Over the course of embryonic development, cells within the developing organ of Corti become committed to develop as each of the unique cell types within the organ, including inner and outer hair cells, and at least four different types of supporting cells. Moreover, these different cell types are subsequently arranged into a highly rigorous cellular mosaic that includes the formation of ordered rows of both hair cells and supporting cells. The events that regulate both the location of the organ of Corti within the cochlear duct, the specification of each cell type and cellular patterning remain poorly understood. However, recent results have significantly improved our understanding of the molecular, genetic and cellular factors that mediate some of the decisions required for the development of this structure. In this review I will present an overview of cochlear development and then discuss some of the most recent and enlightening results regarding the molecular mechanism underlying the formation of this remarkable structure.
\end{abstract}

KEY WORDS: hair cell, ear, otocyst, atoh1, notch

\section{Introduction}

Vertebrates perceive sound, pressure and motion through the vibration of stereociliary bundles located on the lumenal surfaces of mechanosensory hair cells. In most cases, hair cells and associated non-sensory cells, referred to as supporting cells, are arranged in loosely organized clusters that can contain from as few as 10 hair cells in a lateral line neuromast in a fish or salamander (Metcalfe et al., 1985) to more than 200,000 in the macula neglecta of a mature shark (Corwin, 1977). In contrast, the sensory epithelium of the mammalian cochlea (the organ of Corti) contains only a few thousand hair cells but these cells are arranged into four or five discreet rows. Moreover, supporting cells are similarly arranged into highly ordered rows that interdigitate between the rows of hair cells to form an invariant mosaic (reviewed in Kelley, 2006). The factors that regulate the development of this remarkable structure remain largely unknown. However, our understanding of the genes and cellular interactions that mediate its formation has increased considerably in the last 10 years. This review will attempt to summarize recent results that have contributed to advances in our understanding, as well as to summarize the cellular interactions that mediate the progression of cells from otic precursors to differentiated hair cells or supporting cells.

\section{Morphological development of the mammalian cochlear duct}

In mice, the most comprehensive model system for the developing mammalian cochlea, the cochlear duct arises as a ventral out-pocketing of the developing otocyst beginning around E11 (Morsli et al., 1998). By E12 the chirality of the growing duct becomes obvious as it begins to coil. Cochlear extension and coiling will continue until approximately E19 or P0, at which time the duct will have reached it mature shape of approximately 1.75 turns. The duct itself is comprised of pseudostratified epithelial cells derived from the otic placode. Even at the earliest time points following the initiation of cochlear outgrowth, the dorsal half of the duct, typically referred to as the floor, is already comprised of a notably thickened epithelium that contains 5 or 6 layers of cells (Retzius, 1884; Kikuchi and Hilding, 1965; Sher, 1971; Anniko,

Abbreviations used in this paper: $\mathrm{BC}$, border cell; BMP, bone morphogenetic protein; CC, Claudius cell; DC, Deiter cell; HC, Hensen cell; GER, greater epithelial ridge; IHC, inner hair cell; KO, Kollicker's Organ; LER, lesser epithelial ridge; OPC, outer pillar cell; PS, prosensory domain.

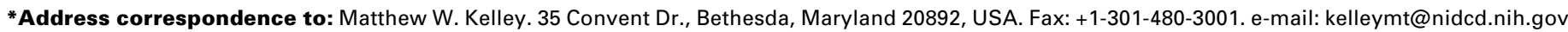


1983; Lim and Anniko, 1985). Between E11 and E13, cells along the modiolar-to-strial axis of the cochlear duct appear largely homogenous. Beginning around E13, cells located in a domain that spans from the approximate midline of the mediolateral axis of the floor to a point midway between the midline and the strial edge become post-mitotic (Ruben, 1967). The most obvious morphological manifestations of this change are the absence of internuclear migration and the basal localization of most cell nuclei (Kelley and Bianchi, 2001). Cells within this post-mitotic region, also referred to as the zone of non-proliferation (ZNP)(Chen and Segil, 1999), are thought to comprise the prosensory domain that will give rise to all of the cells within the organ of Corti (Kelley et al., 1993). While classic lineage analysis studies have not been carried out to confirm that assumption, it has been shown that most of the cells that will develop as hair cells and supporting cells arise from this population of post-mitotic cells (Chen and Segil, 1999; Chen et al., 2002). In addition to a spatial restriction along the modiolar-to-strial axis, terminal mitoses also occur in a stereotypical gradient along the basal-to-apical axis in which cells located at the apex of the cochlear duct are the first to become post-mitotic (Ruben, 1967; Lee et al., 2006). Terminal mitosis then progresses as a wave that extends towards the cochlear base with the last cells becoming post-mitotic between E14 and E14.5. At the lumenal surface, cellular profiles within the prosensory
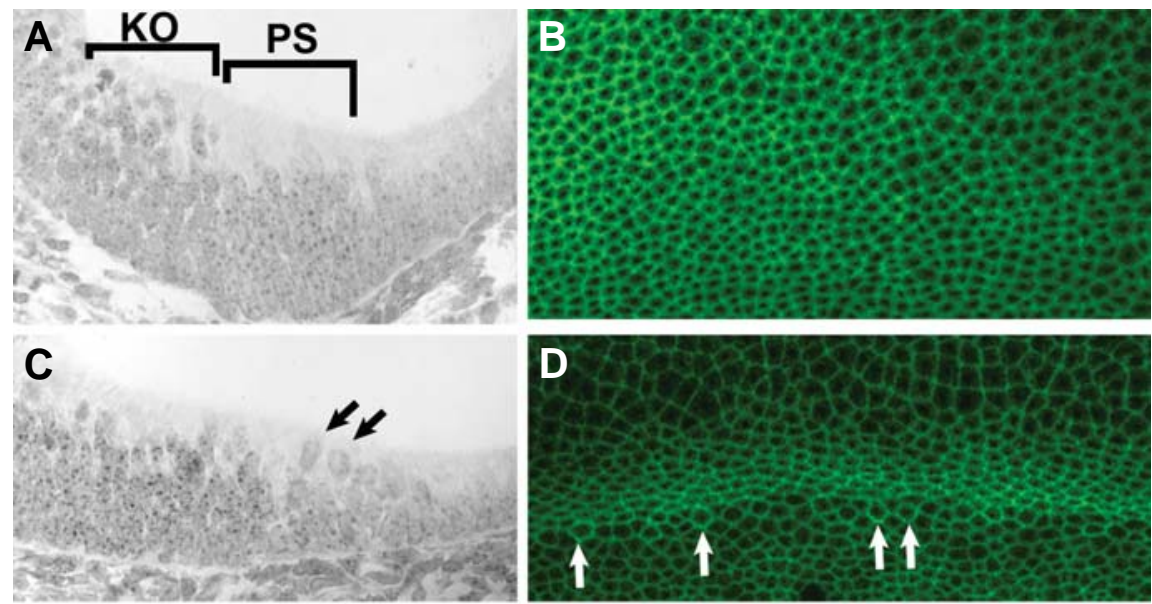

$\mathbf{E}$

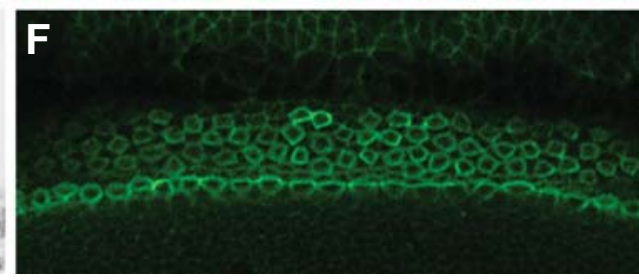

Fig. 1. Development of cellular pattern in the organ of Corti. (A) Cross-section through the mid-basal region of the cochlear duct at E13.5. Nuclei of cells located in the prosensory domain (PS bracket) have moved to a basal position. In contrast, internuclear migration is still ongoing in cells located in Kolliker's organ (KO bracket). (B) View of the lumenal surface of the developing organ of Corti at E13.5. Cell boundaries have been labeled with phalloidin. There are no indications of cellular organization. (C) Cross-section through the cochlear duct at E14.5. Putative developing hair cells (arrows) can be identified in the developing organ of Corti. (D) Lumenal view at E14.5. A few developing inner hair cells are present (arrows). Also, the lumenal projections of adjacent prosensory cells have become constricted. (E) Crosssection of the developing organ of Corti at E16.5. Developing inner and outer hair cell nuclei can now be identified (arrows). (F) In a lumenal view, the basic pattern of the organ of Corti is now evident. domain become constricted relative to surrounding cells leading to a smaller lumenal surface areas (McKenzie etal., 2004)(Fig. 1). The first indication of cellular differentiation within the prosensory fied based on and an increase in the size of their nuclei, a more at their lateral boundaries (Fig. 1). Inner hair cell differentiat then proceeds in a gradient that extends towards both the apex and the base of the cochlear spiral (Rubel, 1978). The order of subsequent cellular differentiation within the organ of Corti re(neveloping outer hair cells can be observed by cells, become morphologically distinct around the same time, making it difficult to determine which cells, if either, arise first. hair cells can arise at a distance of 10 to 15 microns away quent cellular movements may occur to facilitate the final alignobserved in developing outer hair cells, suggesting similar cellular movements (McKenzie et al., 2004).

By $E 17$, hair cells and supporting cells along the length of the cochlear duct have become arranged into the characteristic pattern for the organ of Corti (Fig. 2). A single row of inner hair cells is located on the modiolar edge. Each inner hair cell is separated from the neighboring inner hair cells by a single inner phalangeal cell and the modiolar border of each inner hair cell is typically contacted by a single border cell. The strial edge of each inner hair cell contacts the single row of inner pillar cells, however prior to birth, slender projections from additional inner phalangeal cells are present between inner hair cells and pillar cells. As development proceeds, the developing inner pillar cell head expands to cover the lumenal projection of the strial phalangeal cell. Outer pillar cells are initially aligned in a single row located strial to the inner pillar cells. With continued development, the inner pillar cell head also expands to cover the bulk of the outer pillar cell. However, at the same time, the outer pillar extends a strial projection at the lumenal surface that creates an interdigitation between each of the first row outer hair cells. Since each outer hair cell is separated from each neighboring outer hair cell by a single cell, the number of outer pillar cells and first row outer hair cells is nearly or exactly the same. Outer hair cells in the second row are arranged approximately $1 / 2$ cycle out of register from outer hair cells in the first row and are again separated from one another by single lumenal projections from underlying Deiters' cells. Third row outer hair cells are similarly shifted relative to second row cells, again with single Deiters' 
cells in between each. Finally, the strial edges of the third row outer hair cells are bounded by a single row of Deiters' cell. The number of cells in this row is not as tightly regulated and can be variable in number. Strial to the third row of Deiters' cells are single rows of Hensen's and then Claudius cells. Since there is no strict definition for a supporting cell, it is not completely clear whether Hensen's and Claudius cells should be considered as such. However, they do appear to arise from cells within the ZNP and therefore probably derive from the prosensory domain (Chen and Segil, 1999). Since the cellular pattern of the organ of Corti is essentially complete by $\mathrm{PO}$, the developmental events that regulate its formation occur during the relatively short time period between E10 and P0.

\section{Kolliker's organ and the Greater Epithelial Ridge}

As discussed, only approximately $25 \%$ of the cells within the cochlear duct become part of the prosensory domain. Cells located in the modiolar half of the duct and in the strial-most $25 \%$ ultimately develop as the inner and outer sulci, respectively. In the adult, both sulci are comprised of a monolayer of large cuboidal epithelial cells that appear largely unremarkable. While the cytologic changes that occur during outer sulcus formation have not been studied extensively, remodeling of the inner sulcus cells has been shown to be dependent on thyroid-hormone mediated expression of $\mathrm{p} 75^{\text {tr }}$ leading to cellular apoptosis (Knipper et al., 1999). Elimination of a large percentage of the cells within the developing inner sulcus is consistent with the observation that this region of the cochlear duct contains a large number of cells in the embryo. Moreover, the recent demonstration that cells located within this region of the cochlear duct can develop as either hair cells or supporting cells has resulted in increased interest in this population (Zheng and Gao, 2000; Kawamoto et al., 2003; Woods et al., 2003).

There has been some confusion regarding the precise terminology for these cells. When Zheng and Gao (2000) first demonstrated that transfection of Atoh1 was sufficient to induce hair cell formation in this region of the cochlea, they referred to the cell population as the Greater Epithelial Ridge (GER). However, a subsequent study demonstrating a similar ability for supporting cell formation, referred to these cells as Kolliker's organ (Woods et al., 2004). Considering the increased interest in and relevance of this cell population, it seems reasonable to review the historical data in an effort to identify the most appropriate definition for this population. Albert von Kolliker first described the thickened epithelial cells located in the embryonic cochlear duct in 1863 (Kolliker, 1863). However, it was Victor Hensen that first referred to these cells as Kolliker's organ (Hensen, 1863). While the term Kolliker's organ has been used to describe the immature stage of the organ of Corti (Lim and Rueda, 1992), an examination of the original Kolliker monograph suggests that he was referring to the thickened epithelium that ultimately thins to form the inner sulcus (Fig. 3).

The greater or inner epithelial ridge refers to the thickened ridge of epithelial cells that extends from the modiolar edge of the cochlear duct to a distinct notch that forms at the location of the developing pillar cells (Lim and Anniko, 1985)(Fig. 3). Therefore, the GER contains both Kolliker's organ and those aspects of the organ of Corti, inner hair cells, inner phalangeal cells and border cells, located on the modiolar side of the pillar cells. Whether inner or outer pillar cells should be considered as part of the GER is unclear. Similarly, the lesser or outer epithelial ridge (LER) contains the remainder of the organ of Corti as well as the cells that will ultimately develop as the outer sulcus. While the working definitions of the GER and LER are based on morphology, recent work has demonstrated that the common boundary between the two can also be defined molecularly through the expression of the adhesion molecules Ncad and Ecad (Simonneau et al., 2003). Ncad is expressed in the strial half of Kolliker's organ, inner hair cells and associated supporting cells and inner pillar cells, while Ecad is expressed in outer pillar cells, outer hair cells and associated supporting cells and throughout the LER. In addition, Fgf10 is expressed predominantly in the strial half of GER with a sharp boundary at the border between inner hair cells and pillar cells (Pauley et al., 2003).

Therefore, based on the historical descriptions of this region, it seems that the most appropriate definition for the population of cells located between the prosensory domain and the modiolar edge of the cochlear duct would be Kolliker's organ.

\section{Specification of the cochlear prosensory domain}

As discussed, the first step in the development of the organ of Corti is believed to be the specification of the prosensory domain (Kelley et al., 1993). Our understanding of the factors that mark and specify prosensory domains within the otocyst has increased significantly in recent years, but as will be discussed, there are some important differences in terms of gene expression between the apparent cochlear prosensory domain and other prosensory domains within the otocyst. A number of markers, including

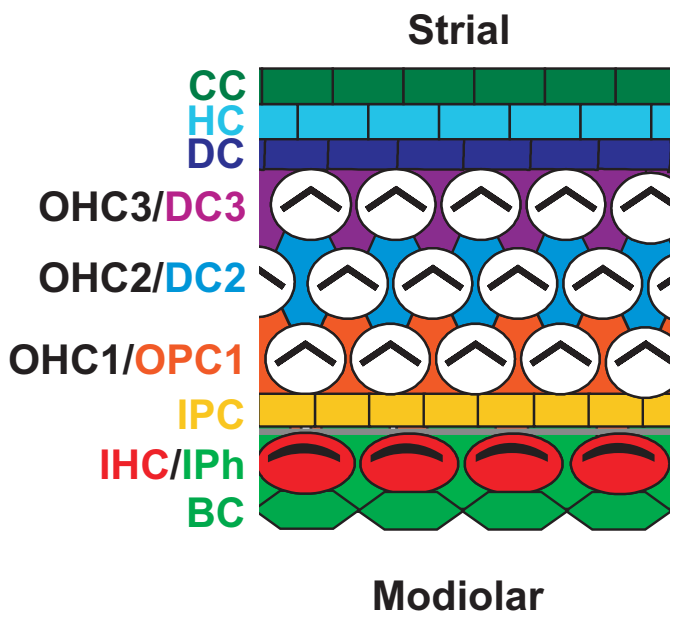

Fig. 2. Schematic diagram of cellular patterning in the organ of Corti at P0. Inner hair cells (IHC) are arranged in a single row located on the modiolar side. Inner hair cells are surrounded by border cells $(B C)$ on their modiolar side and inner phalangeal cells on both their lateral (Iph) and strial (gray) sides. On the strial side of the inner hair cells are single rows of inner (IPC) and outer (OPC) pillar cells. Outer pillar cells also form the interdigitations between first row outer hair cells (OHC1). Second and third row outer hair cells (OHC2/3white) are separated by single Deiters cells (DC2/3). Finally, a third row of Deiters' cells (DC3) from a boundary between the outer hair cells and the adjacent Claudius and Hensen's cells (CC and $\mathrm{HC})$. 
Bmp4, Lunatic Fringe (Lfng), Jagged1/Serrate1 (Jag1), Islet1, Prox1, Sox2 and Fgf16, have all been shown to be expressed in patterns that are consistent, to some extent, with the early development of most prosensory domains (Wu et al., 1996; Morsli et al., 1998; Li et al., 2004; Radde-Gallwitz et al., 2004; Bermingham-McDonogh et al., 2006; Chapman et al., 2006; Pujades et al., 2006). However, functional data for a role in prosensory specification is only available for a much smaller group of candidates that is limited to Bmp4, Jagged1 and Sox2.

\section{Bmp4 and prosensory specification}

The first gene to be shown to be expressed in a pattern consistent with prosensory formation was Bone Morphogenetic Protein 4 (Bmp4)(Wu et al., 1996; Cole et al., 2000). In the chicken, initial expression of bmp4 is observed in a somewhat broad and diffuse pattern along the posterior ventral edge of the developing otic cup. As the cup closes, bmp4 expression resolves to a single posterior ventral spot and an anterior ventral stripe. Subsequently, bmp4 expression can be localized to each of the developing sensory patches. Prior to differentiation, bmp4 is expressed in all cells within the patch, but later becomes restricted to supporting cells. In mice, Bmp4 expression similarly defines the prosensory patches that will give rise to the three cristae, but surprisingly is not expressed in the prosensory patches that will give rise to the utricular or saccular maculae or the organ of Corti (Morsli et al., 1998). However, Bmp4 is expressed in the population of cells located adjacent to the strial edge of the organ of Corti, possible including cells the will develop as Hensen's and Claudius cells.

Based on its pattern of expression and its role in cell fate specification in other systems, Bmp4 appears to be a good candidate to act as a prosensory inducer, at least for a subset of prosensory domains. However, modulation of Bmp4 signalling in developing chick embryos through the ectopic expression of Noggin, a Bmp4 inhibitor, produced equivocal results in terms of a direct role for Bmp4 on prosensory patch formation (Chang et al., 1999; Gerlach et al., 2000). While sensory patches were affected when located near a source of Noggin, the most common change was in cellular patterning rather than in the size of the sensory patch. Since the presence of Noggin results in significant

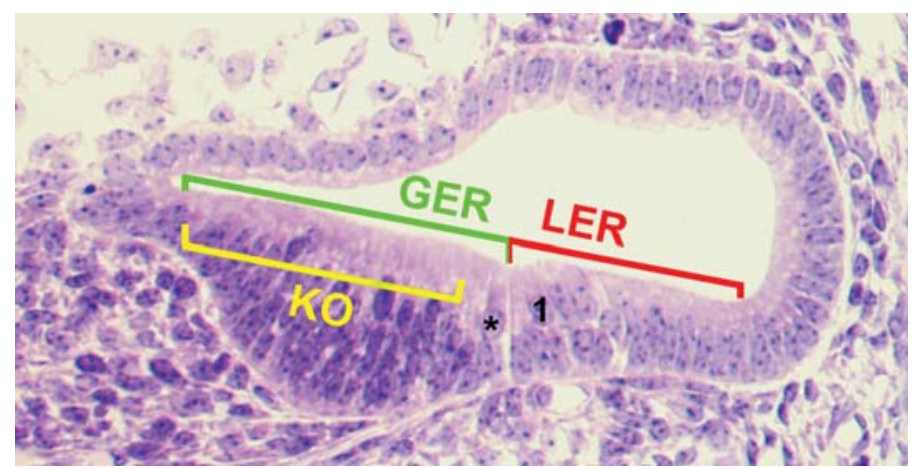

Fig. 3. Kolliker's organ, GER and LER. Cross section through the cochlear duct at E15 illustrating the morphological boundaries of Kolliker's organ (KO), the greater epithelial ridge (GER) and the lesser epithelial ridge (LER). Note the distinct notch that is formed at the GER/LER boundary, marking the position of the pillar cells between the single inner hair cell (*) and first row outer hair cell (1). morphological changes in the overall structure of the inner ear, the basis for the sensory defects was not clear.

More recently, two separate studies addressed the role of Bmp4 in hair cell formation in vitro using chick otocyst cultures. Surprisingly, despite using similar protocols and reagents, the two studies obtained opposing results, with one concluding that Bmp4 promotes hair cell formation ( $\mathrm{Li}$ et al., 2006), while the other indicated an inhibitory role for Bmp4 (Pujades et al., 2006). The basis for these different results is unclear, but may be related to differences in the concentrations of Bmp4 and the duration of the culture period utilized in the two studies. Li et al. (2006) observed a significant increase in hair cell formation in otocysts after 7 days in the presence of 3 to $5 \mathrm{ng} / \mathrm{ml}$ of Bmp4 but also found a downward trend in hair cell number at concentrations between 10 and $20 \mathrm{ng} /$ ml. In contrast, Pujades et al. (2006) observed a decrease in the expression of the early hair cell marker cath1 (chicken Atonal homolog) after only 18 hours in the presence of $50 \mathrm{ng} / \mathrm{ml}$ of Bmp4. Perhaps more intriguing, despite using very similar concentrations of the Bmp-inhibitor Noggin $(0.75 \mathrm{mg} / \mathrm{ml}$ versus $1.0 \mathrm{mg} / \mathrm{ml})$, the two studies reached opposite conclusions about the effects of inhibition of Bmp4, with one finding that hair cell number was decreased ( $\mathrm{Li}$ et al., 2006) while the other found an increase (Pujades et al., 2006). Again, it seems possible that the differences in the durations of the experiments could account for the differing conclusions.

A third experiment examined the role of Bmp4 signalling in the developing mammalian cochlea in vitro (Puligilla et al., 2007). However, in contrast with the experiments described above, modulation of Bmp4 signalling was not initiated until E16, well after the specification of the prosensory domain. The results of these experiments indicated an inductive effect on hair cell formation for Bmp4-soaked beads and an inhibitory effect on hair cell formation in the presence of Noggin. These results would appear to agree with those of Li et al. (2006), but it is important to consider that Bmp4 could act at two different stages in development of inner ear sensory epithelia. In the chick experiments described above, modulation of Bmp signalling was initiated at the otocyst stage, presumably prior to or concomitant with prosensory formation, while the mouse experiments were delayed until a time point that appears to be well past prosensory specification, suggesting that in this case Bmp signalling is acting on the determination of individual cell fates. One of the challenges in differentiating effects on the specification of the prosensory domain versus individual cell fates has been the lack of conclusive markers for prosensory cells. While several genes are initially expressed in all prosensory cells, most, including Jagged1, Sox2, Lfng and $p 27^{\mathrm{kip} 1}$, are maintained in supporting cells, making it difficult to determine specific effects on prosensory formation.

In summary, the existing data on the role of the BMP signalling pathway in the specification of prosensory domains suggests varied and complex activities. However, considering the well documented effects of BMP signalling throughout vertebrate development (reviewed in Massague et al., 2005), it is not surprising that BMP signalling probably plays a similar role in the inner ear. Further studies on the role of this pathway, including an examination of the complex signalling interactions between BMPs and other pathways that regulate aspects of early inner ear formation, such as Fgf, Hedgehog and canonical Wnt signalling (Riccomagno etal., 2002; Wright and Mansour, 2003; Riccomagno 
et al., 2005), should lead to insights into the molecular regulation of prosensory specification.

\section{The Notch signalling pathway is necessary for specification of the prosensory domain}

Two additional genes that are expressed in patterns that are largely consistent with a role in specification of prosensory patches are Jagged1 (Jag1, also referred to as Serrate1 in the chick) and Lunatic Fringe (Lfng, Adam et al., 1998; Cole et al., 2000). Jag1 and Lfng are both components of the Notch signalling pathway, with Jag1 acting as a ligand for Notch, while Lfng modulates the activity of some notch ligands (Bruckner et al., 2000; Moloney et al., 2000). Although both are initially expressed in more diffuse patterns in the otic cup, each ultimately resolves to the developing prosensory regions (Wu et al., 1996, Morsli et al., 1998; Adam et al., 1998; Cole et al., 2000). However, as was the case for Bmp4, Jag1 expression in the mammalian cochlea occurs in a more intriguing pattern. At E12, Jag1 expression in the cochlear duct extends from the modiolar edge of the duct to the mid-point along modiolar-to-strial axis (Morrison et al., 1999; Lanford and Kelley, 2005; Murata et al., 2006). As discussed, this does not appear to correlate with the position of the prosensory domain. By E15, Jag1 expression is localized to the prosensory domain and by E17, Jag1 is expressed exclusively in supporting cells. This pattern of expression raises intriguing questions regarding the development of the cochlear duct and/or Jag1 expression. One possibility would be that individual cells in the modiolar half of the duct transiently express Jag1. Alternatively, Jag1 expressing cells located in the modiolar region of the duct could be relocated to a more strial region of the duct as a result of either morphogenetic changes in the duct itself or through individual cell movements. Pirvola et al. (2002) actually suggested the possibility of exactly this type of cell movements based on the phenotype in Fgfr 1 mutant mice, however, cells exhibiting morphological characteristics consistent with migration or movement, such as cytoplasmic protrusions, have not been reported in Kolliker's organ. It is clear that further experiments, in particular cell lineage and fate mapping of different regions of the cochlear duct will be required to answer these questions.

The role of Notch signalling in the regulation of individual cell fates within individual prosensory domains is well established and will be discussed in a subsequent section. But more recent experiments have illuminated an additional, earlier, role for Notch signalling, in the specification of prosensory domains. In particular, analysis of inner ears from mice in which Jag 1 has either been specifically deleted (Kiernan et al., 2006), or made hypomorphic, reveals a decrease in the overall size of the sensory epithelia (Kiernan et al., 2001; Tsai et al., 2001; Kiernan et al., 2006). In fact, in mice in which Jag1 had been specifically deleted beginning at the early otocyst stage using a FoxG1-dependent Cre expressing line, most of the vestibular organs, with the exception of the saccular maculae, are essentially absent and within the cochlea, a reduced number of mis-patterned hair cells are restricted to the apical region of the duct (Kiernan et al., 2006). Similarly, deletion of $R b p-J k$, a transcriptional repressor that is required for all notch function (de la Pompa et al., 1997; Mizutani et al., 2001), leads to a complete absence of all vestibular epithelia and to a nearly complete loss of all cochlear hair cells as well (Yamamoto and Kelley, unpublished). Finally, inhibition of $\gamma$ - secretase activity, a component of the Notch signalling pathway, inhibits prosensory formation in the chick otocyst (Daudet et al., 2007) Conversely, over-expression of an activated form of chicken notch1, cnotch1-icd (notch-intracellular domain), in non-sensory regions of the chick otocyst leads to the formation of ectopic sensory patches (Daudet et al., 2005). All of these results are consistent with a role for Jag1-dependent Notch activation in the specification of prosensory domains throughout the ear including the cochlear duct.

Despite the ability of over-expression of cnotch1-icd to induce ectopic sensory patches, it seems unlikely that notch 1 is the endogenous receptor for this effect. This conclusion is based on the phenotype in mice in which Notch1 has been specifically deleted in the ear, again using the FoxG1-Creline as a driver. In contrast with inner ear deletion of Jag1, inner ear deletion of Notch1 results in an over-production of hair cells in both the vestibular and cochlear epithelia (Kiernan et al., 2005a). As will be discussed later, the mechanism for this effect is most likely related to the role of Notch signalling in the determination of individual cell fates within prosensory domains. This result suggests that one of the other Notch genes found in both birds (at least 2 additional notch genes)(Hayashi et al., 1996; Myat et al., 1996) and mammals ( 3 additional Notch genes)(reviewed in Katoh and Katoh, 2007) is probably responsible for mediating Jag1-induced prosensory determination. The induction of ectopic patches in response to expression of cnotch1-icd could suggest that induction of prosensory patches only requires an active notch signal and that a specific Notch protein is not required.

The phenotype in Notch1 mutants suggests that Notch1 is not involved in determination of prosensory domains. However, Notch1 is ubiquitously expressed throughout the otocyst beginning at the preplacode stage and extending through to cellular differentiation (Lindsell et al., 1996; Adam et al., 1998; Lanford et al., 1999; Groves and Bronner-Fraser, 2000). Since Jag1 is capable of binding to and activating Notch1 (Hicks et al., 2000; Yang et al., 2005), this suggests that Notch1 activity may be inhibited during the developmental period preceding the determination of individual cell types. The mechanism for this inhibition is unknown, but could be mediated through expression of Fringegenes. Fringe molecules are known to regulate the activity of Notch1 through glycosylation of the receptor leading to suppression of Jag1 induced Notch1 signalling (Hicks et al., 2000; Yang et al., 2005). However, the ability of fringe molecules to suppress notch activation varies between the different notch and fringe molecules. Therefore, while Lunatic Fringe could inhibit Jag1-dependent activation of Notch1 signalling, Jag1 might still be capable of activating notch signalling through a different Notch receptor.

Deletion of $\angle$ fng has no obvious effect on inner ear development (Zhang et al., 2000), suggesting potential functional or compensatory redundancy by Radical or Manic Fringe. In fact, Manic Fringe has been reported to be expressed in the otocyst in both zebrafish and mammals (Johnston et al., 1997; Qiu et al., 2004), but functional redundancy has never been examined. In contrast with the $L$ fngmutants, there is an intriguing phenotype in animals with compound deletion of both Lfng and Jagged? (Jag2). Deletion of Jag2 leads to an over-production of hair cells but deletion of both Jag2and Lfngresults in a partial rescue of the Jag2 phenotype (Zhang et al., 2000). The basis for this effect has not been determined, but one possible explanation could be that 
the loss of Lfng results in ectopic activation of Notch1 through binding of Jag1 during early otocyst development. Since Notch1 appears to mediate an inhibitory pathway, ectopic activation of this pathway could lead to a reduction in the size of the prosensory domain. While this explanation would explain the phenotype that occurs in Jag2/Lfing double mutants, additional experiments are clearly required for confirmation.

\section{Sox2 is necessary for formation of the prosensory domain}

As discussed, activation of the notch signalling pathway is apparently necessary and sufficient to induce the formation of prosensory domains. Considering that the specific Notch molecule involved in prosensory specification has not been determined, it is not surprising that the downstream effectors of this pathway are unknown. However, recent results have suggested that the HMG-box transcription factor Sox2 is a likely target within this pathway. HMG-box transcription factors are known to play an important role in the development of neuronal lineages in all metazoans (Graham et al., 2003) and Sox2 expression in the mammalian inner ear initially correlates with the formation of prosensory domains before ultimately becoming restricted to supporting cells (Uchikawa et al., 1999; Kiernan et al., 2005; Neves et al., 2007). Moreover, prosensory development is either absent or severely reduced in two Sox2 mutant lines (Kiernan et al., 2005). Lcc mice show a complete loss of Sox2 expression in the ear and a complete absence of prosensory domains while $Y s b$ mice have a significant reduction in Sox2 expression in the ear and a corresponding reduction in the size of the prosensory domains. However, while no expression of Sox 2 was observed in Lcc mice at E9.5, the mutation that leads to loss of Sox2 exclusively in the inner ear in this line is uncharacterized. Therefore, it is possible that a limited amount of Sox2 expression might have occurred at very early time points in otic formation.

Sox2 expression is missing in Jag1conditional mutants (Kiernan etal., 2006), suggesting that Jag1-notch signalling acts upstream of Sox2. The specific role of Sox2 in prosensory specification is unclear. Sox 2 has been shown to be necessary for the transition from a proliferating neuroblast to a post-mitotic precursor in the developing CNS (Bylund et al., 2003; Graham et al., 2003) and loss of Sox2 in the inner ear does result in a disruption in the expression of at least one cell cycle regulator, p2 $7^{\mathrm{kip} 1}$, that is known to play a role in prosensory terminal mitosis (Kiernan et al., 2005). However, appropriate assays have not been carried out to determine if loss of Sox2 leads to an increase in cellular proliferation within the prosensory domain.

An intriguing caveat in understanding the role of Sox2 in the ear is the observation that Sox2 expression is not restricted to prosensory domains but is also expressed in precursors of the developing cochlear and vestibular ganglia (Neves et al., 2007). This observation suggests the possibility that Sox 2 is not instructive for prosensory formation but instead might generate a level of competence that would make cells capable of responding to other inductive signals. Consistent with this suggestion, preliminary results from my laboratory suggest that expression of Sox2 is not sufficient to induce prosensory or hair cell fates in Kolliker's organ.

\section{Tbx1 influences formation of prosensory domains}

A final factor that plays a role in the formation of prosensory domains is the Brachyury related transcription factor, Tbx1. Tbx 1 is initially expressed in a posterior-ventral region of the otocyst that correlates with the location of the first expression of Bmp4 (Raft et al., 2004). However, expression of $T b x 1$ is significantly reduced by $\mathrm{E} 12.5$ and it is not clear if Tbx1 is ever expressed in the elongating cochlear duct. Deletion of Tbx1 leads to significant defects in development of inner ear sensory epithelia and to reduced $B m p 4$ expression. Similarly, human mutations in TBX1 lead to DiGeorge syndrome, in which hearing loss is prevalent (Vantrappen et al., 1998). The lack of sensory epithelia in Tbx1 mutants, along with its early pattern of expression, is consistent with a role in prosensory specification. However, it is not clear whether Tbx1 plays a direct role in prosensory specification or acts indirectly through regulation of anterior-posterior patterning within the otocyst (Raft et al., 2004). In fact, several markers of anterior-posterior identity are altered in Tbx 1 mutants (Raft et al., 2004), suggesting a role in otocyst axial patterning. Axial patterning markers are also altered in mice from a BAC transgenic line 316.23, in which TBX1 is broadly expressed throughout the otocyst and the size of sensory regions is increased. These results suggest that changes in the size of the sensory epithelia could be a result of axial re-specification. Therefore, at this point it would be appropriate to directly test the ability of Tbx1 to induce a prosensory domain through forced-expression of Tbx1 within Kolliker's organ.

\section{Fgf signalling in prosensory development}

A final signalling pathway that should be considered as possibly playing a role in prosensory formation is the fibroblast growth factor pathway. Fgfs comprise a family of 22 ligands but only 4 receptors (reviewed in Itoh and Ornitz, 2004). Because Fgf signaling plays a key role in a number of different systems during early embryogenesis including early induction of the otocyst, the ears or entire embryos of many Fgf mouse mutants are disrupted well before cochlear formation (reviewed in Wright and Mansour, 2003). However, the role of Fgfr1 in inner ear development has been examined using both Fgfr1 hypomorphs and conditional deletion of Fgfr1 using FoxG1-Cre (Pirvola et al., 2002). In each case, a dose dependent decrease in the size of the organ of Corti and the expression of Atoh1, was observed. In contrast, the vestibular system was normal. These results suggest a role for Fgfr1 in cochlear development, however because of a lack of appropriate markers at the time of this study, it is difficult to determine the specific role of Fgfr1. However, it should be noted that $p 75^{n t r}$, which is initially expressed in a subset of cells within the cochlear prosensory domain is still expressed in Fgfr flox/ flox; Fox G1cre/t mutants, suggesting that Fgfr1 might act downstream of prosensory formation. More recently, Millimaki et al. (2007) demonstrated that Fgf3 and Fgf8 are required for Atoh1 expression in the xebrafish otocyst, suggesting a role for the Fgf pathway in hair cell commitment.

\section{Regulation of cell number within the cochlear prosensory domain}

Following specification of the prosensory domain, a subsequent important step is regulation of the number of cells within this domain. In many developing neuronal systems, such as the spinal cord, the number of progenitors that are generated typically exceeds the final number of mature neurons and glial cells. As a 
result, unneeded progenitors are eliminated through apoptotic cell death (reviewed in Martin, 2001). However, the level of apoptotic cell death observed within the cochlear prosensory domain is surprisingly small (Chen et al., 2002), suggesting that elimination of unneeded progenitors does not occur. Therefore, regulation of the initial number of cells within the prosensory pool plays a key role in its development. As discussed above, the position of the boundaries of the prosensory domain are determined through a number of still poorly understood molecular signalling pathways. In addition, since prosensory domain formation occurs prior to terminal mitosis, the onset of expression of cell cycle regulators is used as a second regulatory mechanism. In particular, the cyclin kinase inhibitor $\mathrm{p} 27^{\mathrm{kip} 1}$ is initially expressed in the cochlea duct beginning at E12.5 in a pattern that foreshadows the apical-to-basal gradient of terminal mitosis (Chen and Segil, 1999; Lee et al., 2006). Initially, p27kip1 is expressed in all prosensory cells, but by the late embryonic period expression is restricted to developing support cells. Consistent with a role in cell cycle exit, deletion of $p 2{ }^{k i p} 1$ leads to a brief extension in cellular proliferation and to the generation of supernumerary hair cells and supporting cells (Chen and Segil, 1999; Lowenheim et al., 1999). The presence of supernumerary cells within the cochleae

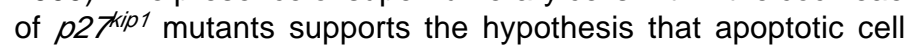
death does not play a significant role in development of cellular patterning within the organ of Corti.

A second cell cycle inhibitor, the pocket protein $p R b$, also regulates terminal mitosis within the cochlear duct. However, $p R b$ expression is apparently delayed relative to $\mathrm{p} 27^{\mathrm{kip} 1}$, with an onset beginning around E15.5 (Mantela etal., 2005). Moreover, expression of $\mathrm{pRb}$ occurs in a basal-to-apical gradient that runs counter to the apical-to-basal gradients of $\mathrm{p} 27^{\mathrm{kip} 1}$ expression and terminal mitosis (Mantela et al., 2005). Finally, the cellular distribution of $\mathrm{pRb}$ is unresolved. While both Mantela et al. (2005) and Sage et al. (2005) reported weak expression of $\mathrm{pRb}$ protein in most cells within the cochlea at E12.5, at later time points Sage et al. reported expression of $\mathrm{pRb}$ in both hair cells and supporting cells, while Mantela et al. only observed pRb expression in hair cells. However, the importance of $\mathrm{pRb}$ was demonstrated in studies that utilized either cre-lox ( $\left.p R b^{f l o x / f l o x} ; \mathrm{Co} / 1 A \gamma^{C r e / t}\right)$ or hypomorphic ( $m g R b: R b^{--}$) rescue strategies to generate $p R b$ mutant mice that survive until birth (Sage et al., 2005; Mantela et al., 2005). Interestingly, both studies reported proliferation defects that were consistent with their observed patterns of expression. Sage et al. reported ongoing proliferation of both hair cells and supporting cells within the cochlea, while Mantela et al. only observed proliferation in hair cells. However, in both studies, a large overproduction of both hair cells and supporting cells was observed. The increased number of supporting cells supports the conclusions of Sage et al. (2005), however it is also possible that the additional supporting cells arose as a result of recruitment from surrounding supernumerary hair cells. Additional studies will be required to resolve the different conclusions from these two studies, at least some of which may be accounted for based on the different strategies used to generate the $p R b$ mutants.

In addition to over-production of hair cells, Mantela et al. (2005) also reported a marked increase in apoptotic hair cell death in $m g R b: R b^{-/-}$mice between E17.5 and E18.5. The basis for this cell death was not clear. Inactivation of $p R b$ has been shown to directly induce apoptosis through the E2f1/p53/Apaf1 pathway
(Morgenbesser et al., 1994; MacLeod et al., 1996; Tsai et al., 1998) but deletion of E2f1 or Apaf1 in the $m g R b: R b^{-/}$background did not abrogate apoptosis, suggesting that other aspects of $p R b$ deletion are responsible for the induction of cell death. Sage et al. (2005) reported no increase in apoptotic cell death in the cochlea in their initial study, but did observe apoptosis in a follow-up study using an alternative Cre-driver (Sage et al., 2006).

Finally, two additional CKIs, p2 $1^{\text {cip } 1}$ and p19ink4d, are also expressed in the prosensory domain beginning between E14.5 and E16.5 (Chen et al., 2003; Laine et al., 2007). Surprisingly, deletion of both genes does not affect the initial pattern of terminal mitosis or cellular differentiation (Laine et al., 2007). However, while deletion of $p 21^{c i p 1}$ has no apparent effect of maintenance of mitotic quiescence (Laine et al., 2007), loss of $p 1$ gink $^{4} d$ results in an increasing rate of spontaneous hair cell mitoses beginning in the postnatal period (Chen et al., 2003). Deletion of both $p 1$ gink4d and $p 21^{c i p 1}$ results in abrupt initiation of mitosis in hair cells beginning on P3 (Laine et al., 2007). In both p19ink4d and $p 19^{\text {ink } 4 \text {; }} p 21^{\text {cip } 1}$ double mutants, cell cycle re-entry is followed by cell death, suggesting that activate proliferation is not compatible with hair cell function (Chen et al., 2003; Laine et al., 2007).

Overall, the results of these studies demonstrate at least two important roles for cell cycle control in cochlear development. First, the timing of terminal mitoses acts as a regulatory mechanism to control the total number of cells within the prosensory domain. As discussed, since naturally occurring apoptotic cell death is rare within the prosensory domain, regulation of cell number is a key mechanism in the determination of prosensory size. Second, maintenance of the post-mitotic state appears to be required for hair cell survival and function and multiple cell cycle inhibitors are expressed within hair cells to ensure mitotic quiescence.

Finally, the unique apical-to-basal patterns of expression of p2 $7^{\mathrm{kip} 1}$ and of terminal mitosis highlight one of the more intriguing aspects of cochlear development. As will be described in the next section, the onset of cellular differentiation in the cochlea also occurs in a gradient that extends along the cochlea, but in this case, it is a basal-to-apical gradient that begins around E14.5 and is not completed until E16.5. As a result, prosensory cells located in the apex of the cochlea become post-mitotic on E12.5 but do not begin to differentiate for another 4 days. In most developing systems there is a very close relationship between cell cycle exit and onset of differentiation (reviewed in Gotz and Huttner, 2005; Nguyen et al., 2006). In fact, bHLH genes have been shown to concurrently antagonize cellular proliferation and induce cellular commitment and differentiation (Farah etal., 2000; Le et al., 2006; Battiste et al., 2007). Therefore, the presence of uncommitted, post-mitotic prosensory cells represents the maintenance of a relatively rare cellular state. The factors that mediate this status and, more importantly, the biological basis for their existence remain to be determined.

\section{Specification of individual phenotypes within the co- chlear prosensory domain}

\section{Atoh1 is a commitment factor for the hair cell fate}

Following specification of the prosensory domain, individual prosensory cells must become determined to develop as all of the unique cell types within the organ of Corti. The first step in this 
process is presently thought to be the onset of expression of the basic helix-loop-helix transcription factor, Atoh1 (formerly Math1), which is initially expressed in a relatively broad and diffuse stripe of cells that begins in the base of the cochlea around E12.5 and extends rapidly towards the apex (Lanford et al., 2000; Woods et al., 2004). Within this stripe, Atoh 1 is weakly expressed in cells located throughout the thickness of the epithelium between the basement membrane and the lumenal surface. As development continues, individual cells with increased levels of Atoh1 expression can be identified within the initially diffuse stripe (Woods et al., 2004). By E16, cells that strongly express Atoh1 can be identified as developing hair cells while intervening, Atoh1-negative cells will develop as supporting cells. Based on this pattern of expression, Atoh 1 is the earliest expressed gene that ultimately becomes restricted to hair cells. It should be noted that some controversy exists regarding the timing and pattern of expression for Atoh1. The pattern described above is based on studies using an Atoh 1 knock-in reporter mouse or in situ hybridization. However, an Atoh1transgenic reporter mouse and immunohistochemistry have indicated that Atoh1 expression does not begin until E14 and is restricted to developing hair cells (Chen et al., 2002; Fritzsch et al., 2005). Finally, PCR amplification was used in a recent study to demonstrate that transcripts for Atoh1are present within the otocyst at E11.5 (Matei et al., 2005). However, since vestibular sensory epithelia were also present in these samples, it was not possible to draw a conclusion regarding expression of Atoh1 in the cochlea at this time point. The reasons for the observed differences in the timing and pattern of Atoh1 expression are not entirely clear. The delay between detection of promoter activity and mRNA versus protein could be a result of a delay in translation or of limited antibody sensitivity. If the antibody has a limited level of sensitivity, then it might only be detectable in cells with high levels of Atoh1 expression. For the transgenic Atoh 1 reporter, the delay appears to be a result of the fact that the transgenic construct does not include all of the Atoh 1 promoter elements and in particular lacks the promoter regions that regulate initial expression of Atoh1 (Lumpkin et al., 2003). However, it is also possible that the results analyzing promoter activity and mRNA could include either non-specific expression of $\beta$-galactosidase in the case of the reporter mouse line or difficulties in discriminating between low levels of Atoh 1 mRNA and background levels of alkaline phosphatase activity in the case of in situ hybridization. Clearly, lineage tracing utilizing an Atoh1-Creknockin mouse should be conducted to resolve issues regarding the initial extend of Atoh1 expression. Similar experiments have been conducted using an Atoh1-Cretransgenic line (Matei et al., 2005), but since this construct also lacks the full complement of Atoh1 promoter elements, the results have the same limitations as the transgenic reporter line discussed above. Even so, the results of these lineage experiments indicated expression of Atoh1 in some types of supporting cells, consistent with the idea that the initial pattern of Atoh1 expression is not limited to hair cells.

The contrasting data regarding the pattern and timing of expression of Atoh1 has lead to multiple hypotheses regarding the specific role of Atoh1. Based on a broader pattern of expression plus the role of the related molecule atonal in Drosophila, Lanford et al. (2000) suggested that Atoh1 acts as a prosensory gene that specifies the population of prosensory cells. In contrast, the more limited pattern of Atoh1 expression observed by anti- body labeling lead to the hypothesis that Atoh1 acts exclusively as a hair cell differentiation factor (Chen et al., 2003). The phenotype in mice with a targeted deletion of Atoh1, which includes a complete absence of hair cells and supporting cells within the cochlea (although some supporting cells, or supporting cell-like cells persist in the vestibular epithelia) is more consistent with a prosensory role, but this phenotype could also be explained by a role for hair cells in supporting cell formation (Woods et al., 2004). In contrast, the expression patterns of Sox2 and p27 $7^{\mathrm{kip} 1}$, both of which are expressed throughout the prosensory domain, are unaffected in Atoh 1 mutants, suggesting that Atoh1 does not play a role in prosensory formation.

To address the role of Atoh1 directly, several laboratories forced cells within Kolliker's organ to express Atoh1. Zheng et al. (2000) demonstrated that continuous expression of Atoh1 leads to the formation of ectopic hair cells in Kolliker's organ in neonatal rat cochlear explant cultures. Woods et al. (2004) transiently expressed Atoh1 in clusters of cells within Kolliker's organ to test the hypothesis that transient activation was sufficient to induce prosensory identity. Although transient activation of Atoh1 was found to be sufficient to induce clusters of cells that included hair cells and supporting cells, subsequent experiments demonstrated that the presence of hair cells is sufficient to induce neighboring cells within Kolliker's organ to develop as supporting cells. Expression of Atoh1 is not required in these neighboring cells, suggesting that while Atoh1 may be expressed in cells that ultimately develop as supporting cells, that expression is not required for those cells to assume a supporting cell fate. Based on these results, Woods et al. (2004) suggested that Atoh1 acts as a hair cell commitment specification factor that, upon expression in the inner ear, acts to launch a molecular program that, if unabated, will ultimately drive a prosensory cell to develop as a hair cell.

The demonstration that cells within Kolliker's organ can be induced to develop as either hair cells, through the expression of Atoh1, or supporting cells, through proximity to a hair cell, suggests that the concept of the prosensory domain as uniquely competent to develop as hair cells and supporting cells may not be correct. Instead, prosensory domains may represent regions within the inner ear that are more permissive for or have a higher likelihood of developing as sensory epithelia. Alternatively, regions of the inner ear that do not develop as sensory may be influenced by inhibitory signals that normally prevent cells in these regions from acquiring either a prosensory or a hair cell fate. Finally, it is also possible that Kolliker's organ represents a unique cellular population that retains an increased ability to develop as prosensory cells. The basis for this ability is unclear, but could be related to the evolutionary history of this region of the cochlear duct.

The results presented above highlight the crucial role of Atoh1 in the formation of hair cells and the organ of Corti. If Atoh1 is initially expressed weakly throughout the prosensory domain, as appears to be the case using some assays, then this expression probably leads to the initial commitment of all of these cells to a hair cell fate and therefore necessitates subsequent cell-cell interactions to limit the number of prosensory cells that ultimately develop as hair cells.

However, a recent paper has cast some doubt on the belief that Atoh1 is absolutely required for hair cell formation. Du et al. (2007) 
generated chimeric mice from wildtype (WT) and Atoh $1 \%$ cells. As would be expected, hair cells derived from WT cells were observed in the inner ears of these animals. But surprisingly, Atoh ${ }^{-}$ - cells were also observed to develop as hair cells. This result suggests that while Atoh1 is required for hair cell formation, that requirement may be relieved by the presence of existing hair cells. An explanation for how such a rescue of the hair cell fate might occur is not obvious, but one possibility would be that existing hair cells are able to induce other cells to activate the hair cell commitment or differentiation program downstream from Atoh1.

\section{Id and notch signaling act to limit Atoh1 expression and hair cell formation}

Atoh1 is a member of the ancient family of bHLH transcription factors (Jones, 2004; Rebeiz etal., 2005). Multiple studies in other systems, in particular Drosophila nervous system, have established specific inhibitory interactions between bHLH molecules and several other signaling pathways. Among these are the notch and id pathways, both of which have been shown to regulate Atoh1 expression in the ear. Ids (Inhibitors of differentiation and DNA binding) are HLH molecules that are closely related to bHLHs in structure but lack the basic domain (reviewed in Norton, 2000; Perk et al., 2005). In order to regulate transcription, bHLH molecules must first form heterodimers with ubiquitously expressed bHLHs, referred to as E-proteins (E2-2, HEP, E12 and E47), through their HLH domains. Following heterodimerization, the basic domains bind to specific DNA recognition sites. Ids lack the basic domain and so are incapable of binding DNA, but act as antagonists of bHLHs through competition for and sequestration of E-proteins. During embryogenesis, /d expression typically decreases around the time that progenitor cells exit the cell cycle and begin to differentiate, a pattern that is consistent with a role in regulating the timing of differentiation (Jen et al., 1996; 1997).

Within the cochlea, three of the four /dgenes, Ids 1,2and 3are broadly expressed between E12 and E14 (Jen et al., 1996; Jones et al., 2006). However, by E16, expression of all three /dgenes is down-regulated in developing hair cells (Jones et al., 2006). The down-regulation of /dexpression correlates with the increase in Atoh1 expression in the same cells and suggests that loss of Id expression could result in the increase in Atoh1 expression that is observed in developing hair cells about this same time. Consistent with this hypothesis, greater than $90 \%$ of prosensory cells that are forced to maintain expression of Id3 beyond the time of down-regulation develop as supporting cells (Jones et al., 2006). In contrast, only $50 \%$ of prosensory cells forced to express a control vector develop as supporting cells.

The notch signaling pathway was discussed at length in the section on prosensory determination as a positive regulator of prosensory fate. However, classic notch signaling has been more commonly associated with inhibitory interactions in which activation of notch prevents progenitor cells from assuming a preferred or "primary" cell fate (reviewed in Ehebauer et al., 2006). Since both notch ligands and receptors are membrane bound, this signaling interaction has often been associated with the formation of cellular mosaics. Based on these results, it is not surprising that notch signaling plays a crucial role in the formation of the cochlear mosaic. Expression studies demonstrated that Notch 1 is broadly expressed within the cochlear duct, including the prosensory domain (Lanford et al., 1999). As cells begin to develop as hair cells, those cells up-regulate expression of two notch ligands, Jagged2 (Jag2) and Delta-like 1 (D//1) with the first signs of ligand expression occurring around E14 in the basal region of the cochlea and subsequently extending towards the apex (Lanford et al., 1999; Morrison et al., 1999). Within 24 hours of ligand expression, activated Notch1 is observed in adjacent cells (Murata et al., 2006) as well as expression of at least two notch target genes, HES1 and HES5 (Zheng et al., 2000; Zine et al., 2001; Lanford et al., 2000). Cells that express HES1 or HES5 will develop as supporting cells. Two other notch target genes, Hey and HeyL may also be expressed in supporting cells but their patterns within the cochlea have not been determined yet.

This pattern of expression is completely consistent with notchmediated lateral inhibition and suggests that developing hair cells inhibit their neighbors from assuming the same fate. There is a large amount of data from developing embryonic mouse cochlea and both developing and regenerating chick basilar papilla that supports this hypothesis. In both systems, ablation of developing or existing hair cells allows neighboring, non-hair cells, to change their fates and to develop as replacement hair cells (Kelley et al., 1995; Adler et al., 1996; Roberson et al., 1996; Roberson et al., 2004; Duncan et al., 2006). At a molecular level, the data is consistent with the hypothesis that notch signaling acts to downregulate the weak expression of Atoh1 that is initially observed in prosensory cells. In particular, deletion of Notch1, Jag2, DI/1, HES1 or HES5leads to an over-production of hair cells (Lanford et al., 1999; Zheng et al., 2000; Zine et al., 2001; Keirnan et al., 2006). Moreover, compound deletion of Jag2 and D//1 results in a larger over-production than either of the single mutants, suggesting an additive effect (Kiernan et al., 2006). Deletion of other genes that regulate Notch signaling, such as $R b p-\mathcal{J}$ (Yamamoto et al., 2006) or COUP-TFI (Tang et al., 2006) also lead to increased production of hair cells. Finally, the initial expression of Atoh1 appears unaffected in Jag2 mutants but a greater number of cells remain Atoh1 positive after the normal onset of Jag2 (Lanford et al., 2000), suggesting that the role of notch signaling is to inhibit Atoh1. This hypothesis is also supported by the demonstration that co-expression of HES1 is sufficient to inhibit the ability of Atoh1 to induce hair cells in Kolliker's organ (Zheng et al., 2000) and by the observation that transient activation of Atoh1 in clusters of Kolliker's organ cells leads to activation of the notch pathway (Woods et al., 2004).

The results discussed above suggest that the sorting of prosensory cells into hair cells and supporting cells occurs through the following interactions. Initially all prosensory cells initiate weak expression of Atoh1, which, if unabated, will lead to hair cell development. At the same time, these same cells are positive for Ids 1,2,3. The presence of Ids prevents Atoh1 from binding to Eproteins and activating transcription of hair cell specific genes. In addition, Atoh1 has been shown to promote its own transcription (Helms et al., 2000), so Id expression may also prevent the activation of a positive feedback loop for Atoh1. Shortly after the onset of Atoh1 expression, Id expression is down-regulated in a subset of cells within the prosensory domain. The factors that mediate this down-regulation in only a small set of cells are unknown. However, once Ids are down-regulated in these cells, repression of the Atoh1 positive feedback loop is removed and these cells are able to increase their level of Atoh1 expression. Among the initial targets of this increased Atoh1 expression are 
the notch ligands Jag2 and DII1. Expression of these ligands in developing hair cells leads to activation of Notch1 (Murata et al., 2006) and expression of the down-stream targets HES1 and HES5 in neighboring cells. The combination of Id expression along with HES1/5 is sufficient to extinguish Atoh1 expression and hair cell commitment in these cells.

\section{Development of supporting cells}

As a result of the Atoh1/ld/Notch signaling interactions described above, cells within the prosensory domain reach a point in which either Atoh1 expression is climbing and the cells are in the process of developing as hair cells or Atoh1 expression is falling or lost, resulting in loss of hair cell commitment. It is this

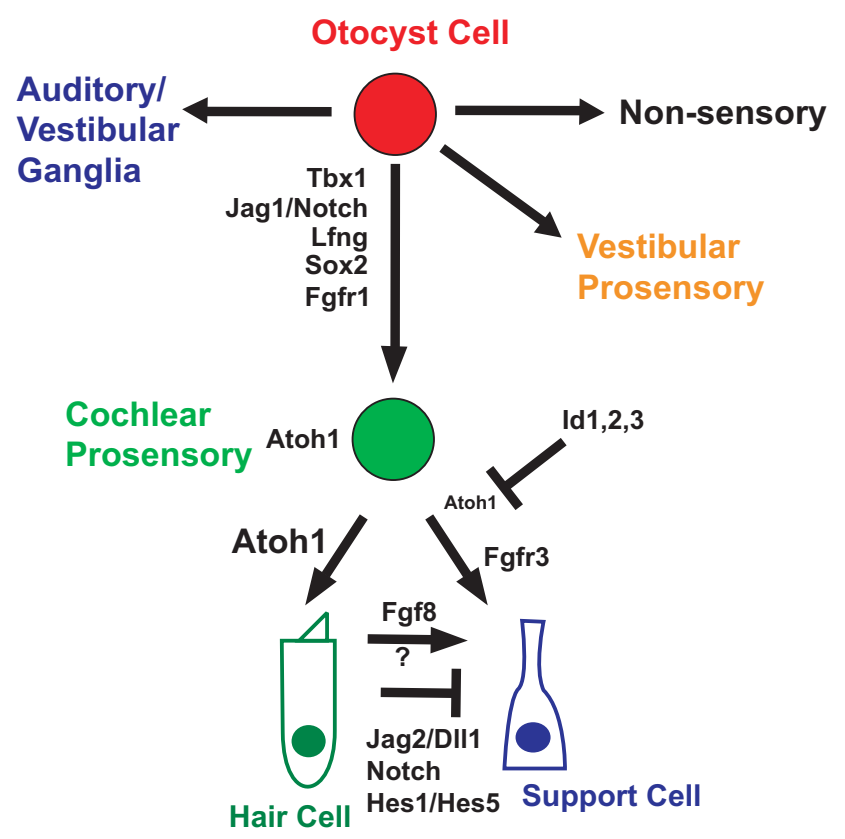

Fig. 4. Determination of cell fates in the organ of Corti. Cells located within the otocyst can develop along one of four different pathways. As cochlear prosensory cells, as closely related vestibular prosensory cells, as cells that will give rise to neurons in the auditory and vestibular ganglia or as non-sensory epithelia. Cells that will develop as cochlear prosensory cells initially express a number of genes that have been shown to play a role in prosensory specification, including Tbx1, Jag1, Lfng, Fgfr1 and Sox2 (see text for details). Following prosensory specification, all prosensory cells express Atoh1 leading to the initiation of a hair cell specification program. At the same time, prosensory cells also express Ids 1, 2 and 3 which act to inhibit Atoh 1 activity. Id expression is subsequently down-regulated in cells that will develop as hair cells, leading to an increase in the level of Atoh 1 expression and the initiation of expression of the notch ligands, Jag2 and DII1. Expression of notch ligands leads to activation of the Notch1 and the downstream target genes HES1 and HES5, in neighboring cells. The presence of HES genes along with continued expression of Ids leads to loss of Atoh 1 expression. At the same time, developing hair cells produce inductive signals, including activation of the Fgf signaling pathway, that recruit surrounding cells to develop as supporting cells. While Fgf signaling clearly plays a role in the development of some types of pillar cells, other unidentified inductive signals (indicated by "?") are also assumed to exist. second population of cells that is assumed to develop as supporting cells. The factors that induce these cells to assume a supporting cell fate are still largely unknown. However, ectopic hair cells located in Kolliker's organ recruit surrounding cells to develop as supporting cells, demonstrating that hair cells generate inductive signals for supporting cell development (Woods et al., 2004).

The molecular nature of the inductive signals for general supporting cell development has not been determined. However, there is evidence for a role for the fibroblast growth factor signaling pathway in the development of pillar cells, a unique supporting cell type within the organ of Corti. Fgfr3 is initially expressed in a population of cells within the cochlear prosensory domain beginning on E15.5 (Peters et al., 1993; Pirvola et al., 1995, Mueller et al., 2002). The expression domain of Fgfr3 appears to include cells that will develop as pillar cells, outer hair cells and Deiters' cells, although definitive lineage tracing has not been conducted. The medial boundary of this domain is fairly sharp and is located directly adjacent to the developing inner hair cells. Deletion or inhibition of Fgfr3 signaling leads to a disruption in both the commitment and differentiation of pillar cells (Colvin et al., 1996; Mueller et al., 2002; Puligilla et al., 2007). In particular, many inner pillar cells are absent, suggesting a defect in commitment, while outer pillar cells are present, but appear undifferentiated (Puligilla et al., 2007). In contrast, deletion of Sprouty2, an Fgfr antagonist that is expressed in a pattern similar to Fgfr3, results in the formation of additional pillar cells (Shim et al., 2005). Finally, Fgf8, an Fgf with a high binding affinity for Fgfr3, is initially expressed exclusively in developing inner hair cells beginning on E15.5, suggesting an inductive interaction between inner hair cells and adjacent progenitor cells (Pirvola et al., 2002; Jacques et al., 2007). Consistent with this hypothesis, conditional deletion of Fgf8also results in defects in pillar cell development, although the phenotype is somewhat less severe than in Fgfr3 mutants (Jacques et al., 2007). Moreover, increased levels of Fgf8 result in increased expression of pillar cell markers in cells within the Fgfr3 expression domain (Jacques et al., 2007).

In addition to a decreased number of pillar cells, cochleae from Fgfr3mutant mice also contain a significantly greater number of outer hair cells, suggesting that Fgfr3 might also act to inhibit hair cell formation, possibly in the region between the inner and outer pillar cells (Puligilla et al., 2007). Analysis of changes in gene expression indicated an increase in Bmp4 signaling in Fgfr3 mutant cochleae and in vitro experiments demonstrated that Bmp4 acts to induce outer hair cell formation. These results provide intriguing data suggesting that Fgf and Bmp signaling pathways might interact within the pillar cell/outer hair cell domain to accurately pattern this region of the organ of Corti.

\section{Summary}

As the cochlear duct extends, its floor becomes partitioned into three regions, a central prosensory domain and two non-sensory flanking domains. Our understanding of the factors that specify the prosensory domain remains limited, but activation of the notch signaling pathway and the transcription factor Sox2 play important roles. Within the prosensory domain, expression of Atoh1 initiates a genetic program that, if unabated, will ultimately lead to the development of a hair cell. However, as a result of cellular and genetic interactions involving the Id and notch signaling path- 
ways, only a subset of cells within the prosensory domain are able to develop as hair cells. Other prosensory cells are diverted from the hair cell fate and are subsequently induced to develop as supporting cells (Fig. 4).

From this summary it is clear that our understanding of the development of the organ of Corti has improved dramatically in the last 10 years. But it should be emphasized that at this point we have only elucidated general signaling interactions that apply to essentially all hair cell epithelia. With the exception of Fgf signaling, the interactions and molecules that regulate the development of the many unique aspects of the organ of Corti, such as the development of inner and outer hair cells and the alignment of cells into ordered rows, remain unknown. Hopefully the continuing examination of the effects of different genetic mutants on cochlear development and the development of better and more specific mouse lines for inner ear or cochlear specific genetic deletion will result in a better understanding of how this fascinating structure develops.

\section{Acknowledgements}

This work was supported by the Intramural Program of the NIDCD/ $\mathrm{NIH}$. The author wishes to apologize to any of his colleagues whose work was not cited in this review because of length constraints.

\section{References}

ADAM, J., MYAT, A., LE ROUX, I., EDDISON, M., HENRIQUE, D., ISH-HOROWICZ, D. and LEWIS, J. (1998). Cell fate choices and the expression of notch, delta and serrate homologues in the chick inner ear: Parallels with drosophila senseorgan development. Development 125: 4645-54.

ADLER, H.J. and RAPHAEL, Y. (1996). New hair cells arise from supporting cell conversion in the acoustically damaged chick inner ear. Neurosci Lett205: 1720.

ANNIKO, M. (1983). Cytodifferentiation of cochlear hair cells. Am J Otolaryngo/4: 375-88.

BATTISTE, J., HELMS, A.W., KIM, E.J., SAVAGE, T.K., LAGACE, D.C., MANDYAM, C.D., EISCH, A.J., MIYOSHI, G. and JOHNSON, J.E. (2007). Ascl1 defines sequentially generated lineage-restricted neuronal and oligodendrocyte precursor cells in the spinal cord. Development 134: 285-93.

BERMINGHAM, N.A., HASSAN, B.A., PRICE, S.D., VOLLRATH, M.A., BEN-ARIE, N., EATOCK, R.A., BELLEN, H.J., LYSAKOWSKI, A. and ZOGHBI, H.Y. (1999). Math1: An essential gene for the generation of inner ear hair cells. Science 284: 1837-41.

BERMINGHAM-MCDONOGH, O., OESTERLE, E.C., STONE, J.S., HUME, C.R., HUYNH, H.M. and HAYASHI, T. (2006). Expression of prox1 during mouse cochlear development. J Comp Neuro/496: 172-86.

BRUCKNER, K., PEREZ, L., ClAUSEN, H. and COHEN, S. (2000). Glycosyltransferase activity of fringe modulates notch-delta interactions. $\mathrm{Na}$ ture 406: 411-5.

BYLUND, M., ANDERSSON, E., NOVITCH, B.G. and MUHR, J. (2003). Vertebrate neurogenesis is counteracted by sox1-3 activity. Nat Neurosci6: 1162-8.

CHANG, W., NUNES, F.D., DE JESUS-ESCOBAR, J.M., HARLAND, R. and WU, D.K. (1999). Ectopic noggin blocks sensory and nonsensory organ morphogenesis in the chicken inner ear. Dev Bio/216: 369-81.

CHAPMAN, S.C., CAI, Q., BLEYL, S.B. and SCHOENWOLF, G.C. (2006). Restricted expression of fgf16 within the developing chick inner ear. Dev Dyn.

CHEN, P., JOHNSON, J.E., ZOGHBI, H.Y. and SEGIL, N. (2002). The role of math1 in inner ear development: Uncoupling the establishment of the sensory primordium from hair cell fate determination. Development 129: 2495-505.

CHEN, P. and SEGIL, N. (1999). P27(kip1) links cell proliferation to morphogenesis in the developing organ of corti. Development 126: 1581-90.

CHEN, P., ZINDY, F., ABDALA, C., LIU, F., LI, X., ROUSSEL, M.F. and SEGIL, N. (2003). Progressive hearing loss in mice lacking the cyclin-dependent kinase inhibitor ink4d. Nat Cel/ Bio/5: 422-6.

COLE, L.K., LE ROUX, I., NUNES, F., LAUFER, E., LEWIS, J. and WU, D.K. (2000) Sensory organ generation in the chicken inner ear: Contributions of bone morphogenetic protein 4, serrate1 and lunatic fringe. J Comp Neuro/424: 50920.

COLVIN, J.S., BOHNE, B.A., HARDING, G.W., MCEWEN, D.G. and ORNITZ, D.M (1996). Skeletal overgrowth and deafness in mice lacking fibroblast growth factor receptor 3. Nat Genet 12: 390-7.

CORWIN, J.T. (1977). Morphology of the macula neglecta in sharks of the genus carcharhinus. J Morpho/152: 341-62.

DAUDET, N., ARIZA-MCNAUGHTON, L. and LEWIS, J. (2007). Notch signalling is needed to maintain, but not to initiate, the formation of prosensory patches in the chick inner ear. Development 134: 2369-78.

DAUDET, N. and LEWIS, J. (2005). Two contrasting roles for notch activity in chick inner ear development: Specification of prosensory patches and lateral inhibition of hair-cell differentiation. Development 132: 541-51.

DE LA POMPA, J.L., WAKEHAM, A., CORREIA, K.M., SAMPER, E., BROWN, S. AGUILERA, R.J., NAKANO, T., HONJO, T., MAK, T.W., ROSSANT, J. et al. (1997). Conservation of the notch signalling pathway in mammalian neurogenesis. Development 124: 1139-48.

DU, X., JENSEN, P., GOLDOWITZ, D. and HAMRE, K.M. (2007). Wild-type cells rescue genotypically math1-null hair cells in the inner ears of chimeric mice. Dev Bio/305: 430-8.

DUNCAN, L.J., MANGIARDI, D.A., MATSUI, J.I., ANDERSON, J.K., MCLAUGHLINWILLIAMSON, K. and COTANCHE, D.A. (2006). Differential expression of unconventional myosins in apoptotic and regenerating chick hair cells confirms two regeneration mechanisms. J Comp Neuro/499: 691-701.

EHEBAUER, M., HAYWARD, P. and MARTINEZ-ARIAS, A. (2006). Notch signaling pathway. SCI STKE2006: $\mathrm{cm} 7$.

FARAH, M.H., OLSON, J.M., SUCIC, H.B., HUME, R.I., TAPSCOTT, S.J. and TURNER, D.L. (2000). Generation of neurons by transient expression of neural bhlh proteins in mammalian cells. Development 127: 693-702.

FRITZSCH, B., MATEI, V.A., NICHOLS, D.H., BERMINGHAM, N., JONES, K., BEISEL, K.W. and WANG, V.Y. (2005). Atoh1 null mice show directed afferent fiber growth to undifferentiated ear sensory epithelia followed by incomplete fiber retention. Dev Dyn 233: 570-83.

GERLACH, L.M., HUTSON, M.R., GERMILLER, J.A., NGUYEN-LUU, D., VICTOR, J.C. and BARALD, K.F. (2000). Addition of the bmp4 antagonist, noggin, disrupts avian inner ear development. Development 127: 45-54.

GOTZ, M. and HUTTNER, W.B. (2005). The cell biology of neurogenesis. Nat Rev Mol Cell Bio/6: 777-88.

GRAHAM, V., KHUDYAKOV, J., ELLIS, P. and PEVNY, L. (2003). Sox2 functions to maintain neural progenitor identity. Neuron 39: 749-65.

GROVES, A.K. and BRONNER-FRASER, M. (2000). Competence, specification and commitment in otic placode induction. Development 127: 3489-99.

HAYASHI, H., MOCHII, M., KODAMA, R., HAMADA, Y., MIZUNO, N., EGUCHI, G. and TACHI, C. (1996). Isolation of a novel chick homolog of serrate and its coexpression with c-notch-1 in chick development. Int J Dev Bio/40: 1089-96.

HELMS, A.W., ABNEY, A.L., BEN-ARIE, N., ZOGHBI, H.Y. and JOHNSON, J.E. (2000). Autoregulation and multiple enhancers control math1 expression in the developing nervous system. Development 127: 1185-96.

HICKS, C., JOHNSTON, S.H., DISIBIO, G., COLLAZO, A., VOGT, T.F. and WEINMASTER, G. (2000). Fringe differentially modulates jagged 1 and delta1 signalling through notch1 and notch2. Nat Cel/ Bio/2: 515-20.

ITOH, N. and ORNITZ, D.M. (2004). Evolution of the fgf and fgfr gene families. Trends Genet 20: 563-9.

JACQUES, B.E., MONTCOUQUIOL, M.E., LAYMAN, E., LEWANDOSKI, M. and KELLEY, M.W. (2007) Fgf8 induces pillar cell fate and regulates cellular patterning in the mammalian cochlea. Development, In Press.

JEN, Y., MANOVA, K. and BENEZRA, R. (1996). Expression patterns of id1, id2 and id 3 are highly related but distinct from that of id4 during mouse embryogenesis. Dev Dyn 207: 235-52.

JEN, Y., MANOVA, K. and BENEZRA, R. (1997). Each member of the id gene family exhibits a unique expression pattern in mouse gastrulation and neurogenesis. Dev Dyn 208: 92-106. 
JOHNSTON, S.H., RAUSKOLB, C., WILSON, R., PRABHAKARAN, B., IRVINE, K.D. and VOGT, T.F. (1997). A family of mammalian fringe genes implicated in boundary determination and the notch pathway. Development 124: 2245-54.

JONES, J.M., MONTCOUQUIOL, M., DABDOUB, A., WOODS, C. and KELLEY, M.W. (2006). Inhibitors of differentiation and DNA binding (ids) regulate math1 and hair cell formation during the development of the organ of corti. $J$ Neurosci 26: $550-8$.

JONES, S. (2004). An overview of the basic helix-loop-helix proteins. Genome Biol 5: 226.

$\mathrm{KATOH}, \mathrm{M}$. (2007). Notch signaling in gastrointestinal tract (review). Int J Onco/30: 247-51.

KAWAMOTO, K., ISHIMOTO, S., MINODA, R., BROUGH, D.E. and RAPHAEL, Y. (2003). Math1 gene transfer generates new cochlear hair cells in mature guinea pigs in vivo. JNeurosci23: 4395-400.

KELLEY, M.W. (2006). Regulation of cell fate in the sensory epithelia of the inner ear. Nat Rev Neurosci7: 837-49.

KELLEY, M.W., TALREJA, D.R. and CORWIN, J.T. (1995). Replacement of hair cells after laser microbeam irradiation in cultured organs of corti from embryonic and neonatal mice. J Neurosci 15: 3013-26.

KELLEY, M.W., XU, X.M., WAGNER, M.A., WARCHOL, M.E. and CORWIN, J.T. (1993). The developing organ of corti contains retinoic acid and forms supernumerary hair cells in response to exogenous retinoic acid in culture. Development 119: 1041-53.

KIERNAN, A.E., CORDES, R., KOPAN, R., GOSSLER, A. and GRIDLEY, T. (2005). The notch ligands dll1 and jag2 act synergistically to regulate hair cell development in the mammalian inner ear. Development 132: 4353-62.

KIERNAN, A.E., PELLING, A.L., LEUNG, K.K., TANG, A.S., BELL, D.M., TEASE, C., LOVELL-BADGE, R., STEEL, K.P. and CHEAH, K.S. (2005). Sox2 is required for sensory organ development in the mammalian inner ear. Nature 434: $1031-5$

KIERNAN, A.E., XU, J. and GRIDLEY, T. (2006). The notch ligand jag1 is required for sensory progenitor development in the mammalian inner ear. PLOS Genet 2: e4.

KIKUCHI, K. and HILDING, D. (1965). The development of the organ of corti in the mouse. Acta Otolaryngo/60: 207-22

KNIPPER, M., GESTWA, L., TEN CATE, W.J., LAUTERMANN, J., BRUGGER, H., MAIER, H., ZIMMERMANN, U., ROHBOCK, K., KOPSCHALL, I., WIECHERS, B. et al. (1999). Distinct thyroid hormone-dependent expression of trkb and p75ngfr in nonneuronal cells during the critical th-dependent period of the cochlea. J Neurobio/38: 338-56.

LAINE, H., DOETZLHOFER, A., MANTELA, J., YLIKOSKI, J., LAIHO, M., ROUSSEL, M.F., SEGIL, N. and PIRVOLA, U. (2007). P19(ink4d) and p21 (cip1) collaborate to maintain the postmitotic state of auditory hair cells, their codeletion leading to DNA damage and p53-mediated apoptosis. J Neurosci 27: 1434-44.

LANFORD, P.J. and KELLEY, M.W. (2005) The Role of the Notch Signaling Pathway in the Development of the Auditory System. In: Development of the Ear (Ed. D.K. Wu, M.W. Kelley, A.N. Popper, R. Fay). Springer-Verlag, New York. 122-157.

LANFORD, P.J., LAN, Y., JIANG, R., LINDSELL, C., WEINMASTER, G., GRIDLEY, T. and KELLEY, M.W. (1999). Notch signalling pathway mediates hair cell development in mammalian cochlea. Nat Genet 21: 289-92.

LANFORD, P.J., SHAILAM, R., NORTON, C.R., GRIDLEY, T. and KELLEY, M.W. (2000). Expression of math1 and hes5 in the cochleae of wildtype and jag2 mutant mice. J Assoc Res Otolaryngo/1: 161-71.

LE, T.T., WROBLEWSKI, E., PATEL, S., RIESENBERG, A.N. and BROWN, N.L. (2006). Math5 is required for both early retinal neuron differentiation and cell cycle progression. Dev Bio/295: 764-78.

LEE, Y.S., LIU, F. and SEGIL, N. (2006). A morphogenetic wave of p27kip1 transcription directs cell cycle exit during organ of corti development. Development 133: 2817-26.

LI, H., CORRALES, C.E., WANG, Z., ZHAO, Y., WANG, Y., LIU, H. and HELLER, S. (2005). Bmp4 signaling is involved in the generation of inner ear sensory epithelia. BMC Dev Bio/5: 16.

LI, H., LIU, H., SAGE, C., HUANG, M., CHEN, Z.Y. and HELLER, S. (2004). Islet1 expression in the developing chicken inner ear. J Comp Neuro/477: 1-10.
LIM, D.J. and ANNIKO, M. (1985). Developmental morphology of the mouse inner ear. A scanning electron microscopic observation. Acta Otolaryngo/Supp/422: 1-69.

LINDSELL, C.E., BOULTER, J., DISIBIO, G., GOSSLER, A. and WEINMASTER G. (1996). Expression patterns of jagged, delta1, notch1, notch2 and notch3 genes identify ligand-receptor pairs that may function in neural development. Mol Cell Neurosci 8: 14-27.

LOWENHEIM, H., FURNESS, D.N., KIL, J., ZINN, C., GULTIG, K., FERO, M.L. FROST, D., GUMMER, A.W., ROBERTS, J.M., RUBEL, E.W. et al. (1999). Gene disruption of p27(kip1) allows cell proliferation in the postnatal and adult organ of corti. Proc Natl Acad Sci USA 96: 4084-8.

LUMPKIN, E.A., COLLISSON, T., PARAB, P., OMER-ABDALLA, A., HAEBERLE, H., CHEN, P., DOETZLHOFER, A., WHITE, P., GROVES, A., SEGIL, N. et al. (2003). Math1-driven gfp expression in the developing nervous system of transgenic mice. Gene Expr Patterns 3: 389-95.

MACLEOD, K.F., HU, Y. and JACKS, T. (1996). Loss of rb activates both p53 dependent and independent cell death pathways in the developing mouse nervous system. Embo J15: 6178-88

MANTELA, J., JIANG, Z., YLIKOSKI, J., FRITZSCH, B., ZACKSENHAUS, E. and PIRVOLA, U. (2005). The retinoblastoma gene pathway regulates the postmitotic state of hair cells of the mouse inner ear. Development 132: 2377-88.

MARTIN, L.J. (2001). Neuronal cell death in nervous system development, disease and injury (review). Int $J$ Mol Med 7: 455-78.

MASSAGUE, J., SEOANE, J. and WOTTON, D. (2005). Smad transcription factors Genes Dev 19: 2783-810.

MATEI, V., PAULEY, S., KAING, S., ROWITCH, D., BEISEL, K.W., MORRIS, K., FENG, F., JONES, K., LEE, J. and FRITZSCH, B. (2005). Smaller inner ea sensory epithelia in neurog 1 null mice are related to earlier hair cell cycle exit. Dev Dyn 234: 633-50.

MCKENZIE, E., KRUPIN, A. and KELLEY, M.W. (2004). Cellular growth and rearrangement during the development of the mammalian organ of corti. Dev Dyn 229: 802-12.

METCALFE, W.K., KIMMEL, C.B. and SCHABTACH, E. (1985). Anatomy of the posterior lateral line system in young larvae of the zebrafish. J Comp Neurol 233: 377-89

MILLIMAKI, B.B., SWEET, E.M., DHASON, M.S. and RILEY, B.B. (2007). Zebrafish atoh1 genes: Classic proneural activity in the inner ear and regulation by fgf and notch. Development 134: 295-305.

MIZUTANI, T., TANIGUCHI, Y., AOKI, T., HASHIMOTO, N. and HONJO, T. (2001) Conservation of the biochemical mechanisms of signal transduction among mammalian notch family members. Proc Nat/ Acad Sci USA 98: 9026-31.

MOLONEY, D.J., PANIN, V.M., JOHNSTON, S.H., CHEN, J., SHAO, L., WILSON, R., WANG, Y., STANLEY, P., IRVINE, K.D., HALTIWANGER, R.S. et al. (2000). Fringe is a glycosyltransferase that modifies notch. Nature 406: 369-75.

MORGENBESSER, S.D., WILLIAMS, B.O., JACKS, T. and DEPINHO, R.A. (1994). P53-dependent apoptosis produced by rb-deficiency in the developing mouse lens. Nature 371: 72-4.

MORRISON, A., HODGETTS, C., GOSSLER, A., HRABE DE ANGELIS, M. and LEWIS, J. (1999). Expression of delta1 and serrate1 (jagged1) in the mouse inner ear. Mech Dev84: 169-72.

MORSLI, H., CHOO, D., RYAN, A., JOHNSON, R. and WU, D.K. (1998). Development of the mouse inner ear and origin of its sensory organs. J Neurosci 18 : 3327-35.

MUELLER, K.L., JACQUES, B.E. and KELLEY, M.W. (2002). Fibroblast growth factor signaling regulates pillar cell development in the organ of corti. JNeurosci 22: 9368-77.

MURATA, J., TOKUNAGA, A., OKANO, H. and KUBO, T. (2006). Mapping of notch activation during cochlear development in mice: Implications for determination of prosensory domain and cell fate diversification. J Comp Neuro/497: 502-18.

MURATA, J., TOKUNAGA, A., OKANO, H. and KUBO, T. (2006). Mapping of notch activation during cochlear development in mice: Implications for determination of prosensory domain and cell fate diversification. J Comp Neuro/497: 502-18.

MYAT, A., HENRIQUE, D., ISH-HOROWICZ, D. and LEWIS, J. (1996). A chick homologue of serrate and its relationship with notch and delta homologues during central neurogenesis. Dev Bio/174: 233-47. 
NEVES, J., KAMAID, A., ALSINA, B. and GIRALDEZ, F. (2007). Differential expression of sox 2 and sox3 in neuronal and sensory progenitors of the developing inner ear of the chick. J Comp Neuro/503: 487-500.

NGUYEN, L., BESSON, A., ROBERTS, J.M. and GUILLEMOT, F. (2006). Coupling cell cycle exit, neuronal differentiation and migration in cortical neurogenesis. Cell Cycle 5: 2314-8.

NORTON, J.D. (2000). Id helix-loop-helix proteins in cell growth, differentiation and tumorigenesis. J Cell Sci113 (Pt 22): 3897-905.

PAULEY, S., WRIGHT, T.J., PIRVOLA, U., ORNITZ, D., BEISEL, K. and FRITZSCH, B. (2003). Expression and function of fgf10 in mammalian inner ear development. Dev Dyn 227: 203-15.

PERK, J., IAVARONE, A. and BENEZRA, R. (2005). Id family of helix-loop-helix proteins in cancer. Nat Rev Cancer 5: 603-14.

PETERS, K., ORNITZ, D., WERNER, S. and WILLIAMS, L. (1993). Unique expression pattern of the fgf receptor 3 gene during mouse organogenesis. Dev Biol155: 423-30.

PIRVOLA, U., CAO, Y., OELLIG, C., SUOQIANG, Z., PETTERSSON, R.F. and YLIKOSKI, J. (1995). The site of action of neuronal acidic fibroblast growth factor is the organ of corti of the rat cochlea. Proc Nat/ Acad Sci USA 92: 926973.

PIRVOLA, U., YLIKOSKI, J., TROKOVIC, R., HEBERT, J.M., MCCONNELL, S.K. and PARTANEN, J. (2002). Fgfr1 is required for the development of the auditory sensory epithelium. Neuron 35: 671-80.

PUJADES, C., KAMAID, A., ALSINA, B. and GIRALDEZ, F. (2006). Bmp-signaling regulates the generation of hair-cells. Dev Bio/292: 55-67.

PULIGILLA, C., FENG, F., ISHIKAWA, K., BERTUZZI, S., DABDOUB, A., GRIFFITH, A.J., FRITZSCH, B. and KELLEY, M.W. (2007). Disruption of fibroblast growth factor receptor 3 signaling results in defects in cellular differentiation, neuronal patterning and hearing impairment. Dev Dyn 236: 1905-1917.

QIU, X., XU, H., HADDON, C., LEWIS, J. and JIANG, Y.J. (2004). Sequence and embryonic expression of three zebrafish fringe genes: Lunatic fringe, radical fringe and manic fringe. Dev Dyn 231: 621-30.

RADDE-GALLWITZ, K., PAN, L., GAN, L., LIN, X., SEGIL, N. and CHEN, P. (2004). Expression of islet1 marks the sensory and neuronal lineages in the mammalian inner ear. J Comp Neuro/477: 412-21.

RAFT, S., NOWOTSCHIN, S., LIAO, J. and MORROW, B.E. (2004). Suppression of neural fate and control of inner ear morphogenesis by tbx1. Development 131: 1801-12.

REBEIZ, M., STONE, T. and POSAKONY, J.W. (2005). An ancient transcriptional regulatory linkage. Dev Bio/281: 299-308.

RICCOMAGNO, M.M., MARTINU, L., MULHEISEN, M., WU, D.K. and EPSTEIN, D.J. (2002). Specification of the mammalian cochlea is dependent on sonic hedgehog. Genes Dev 16: 2365-78.

RICCOMAGNO, M.M., TAKADA, S. and EPSTEIN, D.J. (2005). Wnt-dependent regulation of inner ear morphogenesis is balanced by the opposing and supporting roles of sh. Genes Dev 19: 1612-23.

ROBERSON, D.W., ALOSI, J.A. and COTANCHE, D.A. (2004). Direct transdifferentiation gives rise to the earliest new hair cells in regenerating avian auditory epithelium. JNeurosci Res 78: 461-71.

RUBEN, R.J. (1967). Development of the inner ear of the mouse: A radioautographic study of terminal mitoses. Acta Otolaryngo/Suppl 220:1-44.

RUBEL, E.W (1978) Ontogeny of structure and function in the vertebrate auditory system. In: Handbook of Sensory Physiology, Vol. IX (Ed. M. Jacobson). 135237. Springer, New York.

SAGE, C., HUANG, M., KARIMI, K., GUTIERREZ, G., VOLLRATH, M.A., ZHANG, D.S., GARCIA-ANOVEROS, J., HINDS, P.W., CORWIN, J.T., COREY, D.P. et al. (2005). Proliferation of functional hair cells in vivo in the absence of the retinoblastoma protein. Science 307: 1114-8.
SAGE, C., HUANG, M., VOLLRATH, M.A., BROWN, M.C., HINDS, P.W., COREY, D.P., VETTER, D.E. and CHEN, Z.Y. (2006). Essential role of retinoblastoma protein in mammalian hair cell development and hearing. Proc Nat/ Acad Sci USA 103: 7345-50.

SHER, A.E. (1971). The embryonic and postnatal development of the inner ear of the mouse. Acta Otolaryngol Supp/285: 1-77.

SHIM, K., MINOWADA, G., COLING, D.E. and MARTIN, G.R. (2005). Sprouty2, a mouse deafness gene, regulates cell fate decisions in the auditory sensory epithelium by antagonizing fgf signaling. Dev Cel/8: 553-64.

SIMONNEAU, L., GALLEGO, M. and PUJOL, R. (2003). Comparative expression patterns of t-, n-, e-cadherins, beta-catenin and polysialic acid neural cell adhesion molecule in rat cochlea during development: Implications for the nature of kolliker's organ. J Comp Neuro/459: 113-26.

TANG, L.S., ALGER, H.M. and PEREIRA, F.A. (2006). Coup-tfi controls notch regulation of hair cell and support cell differentiation. Development 133: 368393.

TSAI, H., HARDISTY, R.E., RHODES, C., KIERNAN, A.E., ROBY, P., TYMOWSKALALANNE, Z., MBURU, P., RASTAN, S., HUNTER, A.J., BROWN, S.D. et al. (2001). The mouse slalom mutant demonstrates a role for jagged1 in neuroepithelial patterning in the organ of corti. Hum Mol Genet 10: 507-12.

TSAI, K.Y., HU, Y., MACLEOD, K.F., CROWLEY, D., YAMASAKI, L. and JACKS, T. (1998). Mutation of e2f-1 suppresses apoptosis and inappropriate s phase entry and extends survival of rb-deficient mouse embryos. Mo/ Cel/2: 293-304.

UCHIKAWA, M., KAMACHI, Y. and KONDOH, H. (1999). Two distinct subgroups of group b sox genes for transcriptional activators and repressors: Their expression during embryonic organogenesis of the chicken. Mech Dev84: 10320.

VANTRAPPEN, G., ROMMEL, N., CREMERS, C.W., DEVRIENDT, K. and FRIJNS, J.P. (1998). The velo-cardio-facial syndrome: The otorhinolaryngeal manifestations and implications. Int J Pediatr Otorhinolaryngo/45: 133-41.

WOODS, C., MONTCOUQUIOL, M. and KELLEY, M.W. (2004). Math1 regulates development of the sensory epithelium in the mammalian cochlea. NatNeurosci 7: $1310-8$.

WRIGHT, T.J. and MANSOUR, S.L. (2003). Fgf3 and fgf10 are required for mouse otic placode induction. Development 130: 3379-90.

WRIGHT, T.J. and MANSOUR, S.L. (2003). Fgf signaling in ear development and innervation. Curr Top Dev Bio/57: 225-59.

WU, D.K. and OH, S.H. (1996). Sensory organ generation in the chick inner ear. $J$ Neurosci 16: 6454-62.

YAMAMOTO, N., TANIGAKI, K., TSUJI, M., YABE, D., ITO, J. and HONJO, T. (2006). Inhibition of notch/rbp-j signaling induces hair cell formation in neonate mouse cochleas. $J$ Mol Med 84: 37-45.

YANG, L.T., NICHOLS, J.T., YAO, C., MANILAY, J.O., ROBEY, E.A. and WEINMASTER, G. (2005). Fringe glycosyltransferases differentially modulate notch1 proteolysis induced by delta1 and jagged1. Mol Biol Cel/16: 927-42.

ZHANG, N., MARTIN, G.V., KELLEY, M.W. and GRIDLEY, T. (2000). A mutation in the lunatic fringe gene suppresses the effects of a jagged2 mutation on inner hair cell development in the cochlea. Curr Bio/10: 659-62.

ZHENG, J.L. and GAO, W.Q. (2000). Overexpression of math1 induces robust production of extra hair cells in postnatal rat inner ears. Nat Neurosci3: 580-6.

ZHENG, J.L., SHOU, J., GUILLEMOT, F., KAGEYAMA, R. and GAO, W.Q. (2000). Hes1 is a negative regulator of inner ear hair cell differentiation. Development 127: 4551-60.

ZINE, A., AUBERT, A., QIU, J., THERIANOS, S., GUILLEMOT, F., KAGEYAMA, R. and DE RIBAUPIERRE, F. (2001). Hes 1 and hes 5 activities are required for the normal development of the hair cells in the mammalian inner ear. JNeurosci21: 4712-20.

Published Online: 19th September 2007 
Related, previously published Int. J. Dev. Biol. articles

See our Special Issue Ear Development edited by Fernando Giraldez and Bernd Fritzsch at: http://www.ijdb.ehu.es/web/contents. php?vol=51\&issue=6-7

Analysis of Netrin 1 receptors during inner ear development

Tanja Matilainen, Maarja Haugas, Jordan A. Kreidberg and Marjo Salminen

Int. J. Dev. Biol. (2007) 51: 409-414

Axon guidance in the inner ear

Donna M. Fekete and Andrea M. Campero

Int. J. Dev. Biol. (2007) 51

Cell proliferation during the early compartmentalization of the Xenopus laevis inner ear Quincy A. Quick and Elba E. Serrano

Int. J. Dev. Biol. (2007) 51: 201-210

Interplay between FGF10 and Notch signalling is required for the self-renewal of pancreatic progenitors Francisco Miralles, Luciane Lamotte, Dominique Couton and Rajiv L. Joshi

Int. J. Dev. Biol. (2006) 50: 17-26

Notch in vertebrates - molecular aspects of the signal

Ken-Ichi Katsube and Kei Sakamoto

Int. J. Dev. Biol. (2005) 49: 369-374

Transdifferentiation of corneal epithelium: evidence for a linkage between the segregation of epidermal stem cells and the induction of hair follicles during embryogenesis.

David J Pearton, Corinne Ferraris and Danielle Dhouailly

Int. J. Dev. Biol. (2004) 48: 197-201 